\title{
The Impact of Personal Attitude, Subjective Norm, and Perceived Behavioural Control on Entrepreneurial Intentions of Women
}

\author{
M. Sait DINC* , Semira BUDIC ${ }^{* *}$
}

\begin{abstract}
In the last decade, female entrepreneurship has been identified as one of the most important unutilised sources of economic growth. Entrepreneurial intention of women has become a key element in establishing a new business. The factors influencing entrepreneurial intention of women, particularly in developing countries, have attracted curiosity lot of attention. The purpose of the study is to examine the relationship between demographic variables, personal attitude, subjective norm, perceived behavioural control, and entrepreneurial intentions of women in Federation of Bosnia and Herzegovina. A total of 216 questionnaires were collected from women in two big cities in Bosnia: Tuzla and Sarajevo. Relationships between the variables were evaluated using factor analysis, reliability, correlations, descriptive statistics, and regression. The findings show a positive and significant influence of personal attitude and perceived behavioural control on entrepreneurial intention.
\end{abstract}

Keywords: Entrepreneurial intention of women, personal attitude, subjective norm, perceived behavioural control, Federation of Bosnia and Herzegovina.

JEL Classification Codes: L2

UDC: 331.445

DOI: https://doi.org/10.17015/ejbe.2016.017.02

\footnotetext{
* Assistant Professor, Department of Management, International Burch University, Bosnia and Herzegovina. E-mail: sdinc@ibu.edu.ba

** International Burch University, Bosnia and Herzegovina. E-mail: semirabudic@hotmail.com 


\section{Introduction}

Entrepreneurship is the most important instrument for stimulating a nation's economic growth and development. In the developing world successful small and medium companies are the main reasons for poverty reduction and job creation (Bianchi \& Henrekson, 2005; Reynolds, Bygrave, Autio, \& Hay, 2002). Entrepreneurship leads to higher standards of living, higher income generation, higher government revenue, and higher individual savings. In the last decade, entrepreneurs have changed the scene of trade and markets through new technologies, produced commodities, and services (Oke, 2013). However, there is a raising awareness that women entrepreneurs are the new generators of sustainable growth (GEM, 2012). Numerous stakeholders have noticed that they are the 'rising stars of the economies', 'the way forward', and 'the untapped source of economic growth and development' (Vossenberg, 2013; Ahl, 2006; Pearson, 2007). Estimates show that by 2020, 870 million women will enter the economic mainstream for the first time, which might affect productivity and GDP growth rates by as much as $34 \%$ and $25 \%$ increase respectively in some countries (World Bank, 2011). On the other hand, female entrepreneurship is still identified as an important unutilised source of economic growth.

Based on the presumption that intention is the best predictor of behaviour (Ajzen, 1991), this research tries to test Ajzen's (1991) theory of planned behaviour as a proposed model (See Figure 1) for checking how entrepreneurial intention (EI) is determined by one's personal attitude (PA) toward the entrepreneurship, perceived subjective norms (SN), and perceived behavioural control (PBC) which are influenced by demographic factors. A number of works dealing with this matter in developed countries have been published lately, but there is a scarcity of literature that addresses the issue in developing countries and transition economies (Friedman, Aziz, Keles, \& Sayfullin, 2012). A lot of research is still required in order to better comprehend which factors affect entrepreneurial intentions of women, especially in the context of developing countries.

Federation of Bosnia and Herzegovina $(\mathrm{FBiH})$ is a transitional and developing country in Balkan region. After signing the Dayton agreement in 1995 which ended the brutal conflict from 1992 to 1995, BiH has started recovering and the economy has been developing slowly with the help of developed countries (Dinc \& Huric, 2016). Today, general intentions of people in $\mathrm{FBiH}$ to start companies are increasing due to high unemployment rates. In the past few years, the number of new companies has soared significantly, but the data from 2014 GEM report still shows that the growth and expansion aspirations are low. A lot of entrepreneurs do not expect to employ more than five new employees in the next five years. Supportive factors that influence entrepreneurship in $\mathrm{FBiH}$ are positive social status and attitude towards entrepreneurship, physical infrastructure, and good internal market dynamics. However, political instability and inadequate programs and policies from government are holding down the entrepreneurial expansion. New 
policies and high multiple taxes are obstacles to engaging in entrepreneurial activities. For the purpose of creating policies and programs that will encourage and support entrepreneurial behaviour, especially that of women, it is crucial to understand the main factors that influence and shape individual's intentions when deciding to create companies. Therefore the purpose of this study is to examine the impact of antecedent factors of PA, SN, and PBC which are affected by demographic variables on El.

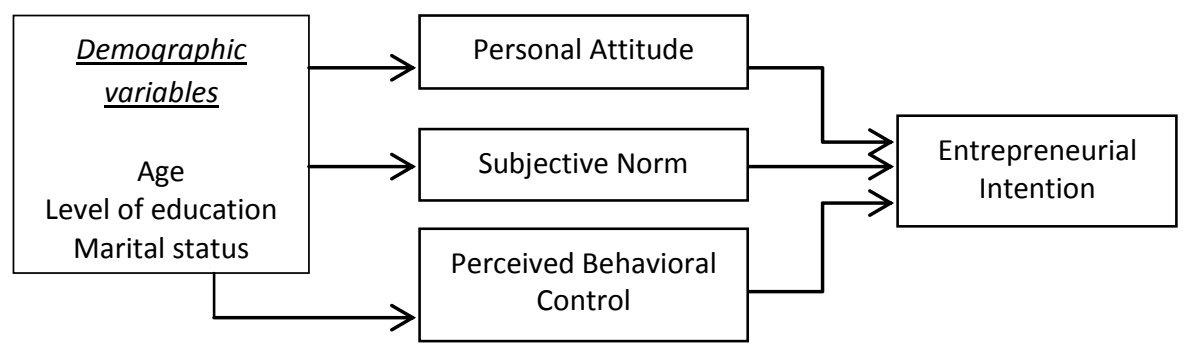

Figure 1. Proposed Entrepreneurial Intention Model

\section{Literature review and hypothesis development}

The decision to engage in entrepreneurship is seen as a voluntary will of an individual (Liñán \& Chen, 2009; Krueger, Reilly, M.D., \& Carsrud, 2000). But, how do people come to the stage to make those decisions? Since intention is part of psychological processes, it has been revised and examined by numerous researchers and theorists. According to Bird (1988) intentionality is a determination or condition of mind that guides a person's focus on particular matter in order to accomplish a specific goal. Modern researchers place intention as a single variable within bigger psychological processes. Fishbein and Ajzen (1975) indicated the significance of intentional elements such as belief, focus, and expectation, focusing on how they impact actual behaviour of an individual. A precondition to the creation of a new venture is entrepreneurial intention (Liñán \& Chen, 2009; Fayolle et al., 2006; Kolvereid, 1996; Koe \& Abdul Majid, 2014). As Bird (1988) stated, entrepreneurial intentions are aimed at either creating a new venture or adding values to existing companies. However, before actually performing entrepreneurial behaviour, the intention might be affected by numerous factors, such as needs, wants, values, beliefs, and habits (Liñán \& Chen, 2009; Bird, 1988; Lee \&Wong, 2004). There are two models of entrepreneurial intention found in the literature: Shapero's (1975) 'Entrepreneurial Event Model' and Ajzen's (1991) 'Theory of Planned Behaviour' (TPB). The first model presents entrepreneurial intention as a desire or wish to engage in entreprenurship whereas the second model poses three main factors that impact entreprenurial intentions.

According to Gelderen, Brand, Praag, Bodewes, Poutsma, \& Vangils (2006), the most frequently used model in previous studies of entrepreneurial intentions is 
TPB. This model explains the interaction between environmental and personal factors and their impact on entrepreneurial intentions (Sivarajah, \& Achchuthan, 2013). Key motivational factors, the so called antecedents in theory of planned behaviour, which impact behaviour of an individual are personal attitude (PA), subjective norm (SN), and perceived behavioural control (PBC) (Ajzen, 1991; Liñán, 2004). This cognitive approach in the research field of entrepreneurship highlights the importance of perceptions of entrepreneurship rather than the personal characteristics of the entrepreneur (Sivarajah, \& Achchuthan, 2013; Shaver \& Scott, 1991). These factors are the predictors of how much the individual is prepared to invest into the performance of the task. The stronger the will to engage in particular activity, the higher the probability to actually end up exercising that specific behaviour.

The impact of PA, SN and PBC on El is expected to vary under the impact of other variables in different situations. These variables might be found in the form of situational factors (Liñán \& Chen, 2009; Ajzen, 1987; Boyd \& Vozikis, 1994; Tubbs \& Ekeberg, 1991). Those situational factors sometimes appear as time constraints, and sometimes as the difficulty or ease of performing a task (Krueger, 1993; Liñán \& Chen, 2009; Lee \& Wong, 2004). Therefore, through previous research and the application of the model in different contexts, it was found that in some cases only attitudes exhibited significant impact on intentions, whereas in some other cases PA as well as PBC had a great impact on intentions. On the other hand, all three factors made independent contributions in many other studies (Liñán \& Chen, 2009). Generally, measuring cognitive variables is a very difficult task (Baron, 1998). The reasons for these conflicting results might be measurement issues (Chandler \& Lyon, 2001). Kolvereid (1996) relied on a belief-based measure of attitudes, whereas Krueger, Reilly \& Carsrud (2000) tried to measure each construct by using single-item variables. Some of the previous studies tried to convince the participants to express their preferences and based on their answers they estimated likelihoods of pursuing a self-employment career instead of regular employment in random company (Liñán \& Chen, 2009; Erikson, 1999; Fayolle et al., 2006; Kolvereid, 1996). Despite thementioned conflicts in the field of literature, the results from numerous previous studies have generally supported the application of the TPB to entrepreneurship (Liñán \& Chen, 2009).

Personal attitude, $(P A)$ is a personal standing or the mindset on a particular issue. In this precise framework, it refers to the attitude toward venture creation. PA indicates the individual's belief about becoming an entrepreneur (Liñán \& Chen, 2009; Ajzen, 2001; Autio et al., 2001; Kolvereid, 1996). Eagly \& Chaiken (1993) stated that the attitude is a tendency to make positive or negative evaluations on precise issues or entities. This psychological trait exists in every human being in theform of critical observation and evaluation. Shook \& Bratianu (2010) argue that the attitude of an individual toward a specific issue depends on his or her beliefs about the end result. The more positive the final result is, the better perception of 
The Impact of Personal Attitude, Subjective Norm, and Perceived Behavioural Control on ...

it. And the better the perception of it, the firmer the intention to exercise specific behaviour.

Subjective norm $(S N)$ refers to the extent to which relevant persons or individuals support or do not support the performance of a particular behaviour. In research, $\mathrm{SN}$ is commonly measured by asking participants to what extent they think their closest ones - family members, friends, or colleagues - would support them in engaging in entrepreneurial activities (Liñán \& Chen, 2009; Ajzen, 2001). Since these perceptions of individuals are subjective in their very nature, this factor is entitled as a subjective norm (Fishbein \& Ajzen, 1975).

Perceived behavioural control $(P B C)$ is the perception of an individual of the ease or difficulty of carrying out the task of starting and running a company. PBC is a significant factor in the theory of planned behaviour. Atkinson's (1964) theory of achievement motivation contains some elements of perceived behavioural control. It is described as the perceived probability to succeed at performing a specific task. The theory of planned behaviour is distinguished from the previous theory of reasoned action by Ajzen (1991) in the fact that it introduces PBC. The theory of planned behaviour proposes that PBC, along with behavioural intention, might be a good predictor of the achievements of an individual in a specific field. Majority of the work done in the field of perceived behavioural control is done by Bandura and his associates (Adams, \& Beyer, 1977; Bandura, Adams, Hardy, \& Howells, 1980). Beliefs about self-efficacy to a great extent impact the choice of tasks, the effort invested into that specific task, as well as a person's thoughts and emotional stability (Bandura, 1981).

Ajzen distinguishes perceived behavioral control from the locus of control introduced by Rotter (1966). The locus of control does not change over time, but stays relatively stable, whereas perceived behavioural control might change over time. The locus of control states that someone's success depends on the effort invested (Rotter, 1966). According to the literature mentioned above, the following hypotheses can be posited:

Hypothesis 1: PA has a positive and significant influence on El.

Hypothesis 2: PBC has a positive and significant influence on El.

Hypothesis 3: SN has a positive and significant influence on El.

Hypothesis 4: SN has a positive and significant influence on PA.

Hypothesis 5: SN has a positive and significant influence on PBC.

Hypothesis 6 Demographic variables have a positive and significant influence on PA. Hypothesis 7: Demographic variables have a positive and significant influence on SN.

Hypothesis 8: Demographic variables have a positive and significant influence on PBC. 


\section{Research method}

\subsection{Sample and data collection}

FBiH has 10 cantons with different administrative and judiciary systems. Respondents were women of all ages in two of the cantons: Tuzla and Sarajevo. These two cities were selected because they are the two biggest cities in $\mathrm{FBiH}$ in terms of population. An online questionnaire was posted on several online platforms. Participation was completely voluntary. The research on female entrepreneurial intentions was conducted in the period from April to May 2016.

As it can be seen in Table 1, the majority of respondents were women aged 18-24. The majority of these women (44,2 \%) are employed. Most of the women respondents $(64,7 \%)$ in the study obtained at least a bachelor degree. While the majority of the respondents $(72,6 \%)$ were from Sarajevo Canton, some of them $(27,4 \%)$ were from Tuzla Canton. The majority of women $(68,4 \%)$ were single.

\section{Table 1. Sample Characteristics}

\begin{tabular}{llcc}
\hline Variable & Demographics & Number & Valid Percent \\
\hline Age & 18-24 years & 99 & 46 \\
& 25-34 years & 87 & 40,5 \\
& 35-44 years & 24 & 11,2 \\
& $45-55$ years & 4 & 1,9 \\
Employment & over 55 years & 1 & 0,5 \\
& Employed & 95 & 44,2 \\
Education Level & Unemployed & 120 & 55,8 \\
& Primary school & 10 & 4,7 \\
& High school & 66 & 30,7 \\
& Bachelor degree & 83 & 38,6 \\
& Master degree & 52 & 24,2 \\
Marital Status & Phd & 4 & 1,9 \\
& Married & 68 & 31,6 \\
Residence & Single & 147 & 68,4 \\
& Sarajevo & 156 & 72,6 \\
N=215 & Tuzla & 59 & 27,4 \\
\hline
\end{tabular}

\subsection{Instruments and measures}

A two-page questionnaire with five sections was used to collect data. Four sections of the questionnaire included questions about PA, SN, PBC, and El. The questions were adapted from Entrepreneurial Intention Questionnaire developed by Liñán 
The Impact of Personal Attitude, Subjective Norm, and Perceived Behavioural Control on ...

and Chen (2009). These two authors based the questionnaire on the theoretical background and empirical research of previous researchers, as well as Ajzen's work directly (1991, 2001). The EIQ form contained 25 mandatory questions grouped into four specific sections. After they extracted some items, the EIQ was divided into 4 main parts. The PA section included five questions while the SN section had three questions. The last two sections, $\mathrm{PBC}$ and $\mathrm{EI}$, consisted of six questions each. All questions were measured using a 5-point Likert scale, starting from 1-strongly disagree to 5 -strongly agree.

Since the questionnaire was prepared in English, it had to be translated to the Bosnian language. The translation was done independently by two experts in English language and literature and Bosnian native speakers. In order to resolve all discrepancies, a pilot study was performed with female professors, assistants, and administrative staff at a private university to check the feasibility of the questions in the survey. After evaluating and correcting the ambiguous questions, the survey was ready for data collection.

\subsection{Data analyses}

After collecting data descriptive analyses in SPSS 18 software program was performed for the purpose of understanding the results of the study. Through individual analyses the data was summarised and the mean, standard deviation, and variance of the sample were calculated. After clarifying variables by using the exploratory factor analyses, the reliability of the variables was tested using Cronbach's alpha coefficients. Pearson's correlation was also done in order to analyze the relationship among variables. Finally, in order to measure the effects of PA, SN, and PBC on entrepreneurial intention, regression analyses were used. The results are interpreted in the following section.

\section{Results}

\subsection{Initial analyses}

The first step in analysing data was checking the validity of the four scales for which purpose we used the exploratory factor analysis. All scales were analyzed. In the process, we used the principal component analysis as the factor extraction method, and the varimax method for the component rotations. In the first run, four variables emerged consistent with the literature. The next step in the analysis of the results was using Cronbach's alpha to test the reliability of the scales. According to Nunnally (1978), a score above 0.7 is considered reliable. In this study, the Cronbach's alpha values of all scales range from 0.78 to 0.94 . Thus, the scales can be considered reliable. The factor loadings and coefficient alpha of all scales are presented in Table 2. 


\section{Table 2. Factor Loadings and Coefficient Alpha for Personal Attitude, Subjective Norm, Perceived Behavioral Control and Entrepreneurial Intention}

\begin{tabular}{|c|c|c|}
\hline Variables and Items & $\begin{array}{c}\text { Factor } \\
\text { Loading }\end{array}$ & $\begin{array}{c}\text { Chronbach's } \\
\text { Alpha }\end{array}$ \\
\hline Personal Attitude & & 0.894 \\
\hline Being an entrepreneur would entail great satisfactions for me & 0.823 & \\
\hline $\begin{array}{l}\text { Being an entrepreneur implies to me more advantages than } \\
\text { disadvantages }\end{array}$ & 0.732 & \\
\hline A career of entrepreneur is very attractive for me & 0.779 & \\
\hline $\begin{array}{l}\text { If I had the opportunity and resources, I'd like to start a } \\
\text { company }\end{array}$ & 0.749 & \\
\hline Among various options, I would rather be an entrepreneur & 0.684 & \\
\hline Subjective Norm & & 0.780 \\
\hline $\begin{array}{l}\text { If I decided to create a company my close family would approve } \\
\text { of that decision }\end{array}$ & 0.848 & \\
\hline $\begin{array}{l}\text { If I decided to create a company my friends would approve of } \\
\text { that decision }\end{array}$ & 0.807 & \\
\hline $\begin{array}{l}\text { If I decided to create a company my colleagues would approve } \\
\text { of that decision. }\end{array}$ & 0.741 & \\
\hline 3. Perceived Behavioral Control & & 0.875 \\
\hline I know the necessary practical details to start a firm & 0.796 & \\
\hline I can control the creation process of a new firm & 0.778 & \\
\hline To start a firm and keep it working would be easy for me & 0.724 & \\
\hline I am prepared to start a viable firm & 0.678 & \\
\hline I know how to develop an entrepreneurial project & 0.670 & \\
\hline $\begin{array}{l}\text { If I tried to start a firm, I would have a high probability of } \\
\text { succeeding }\end{array}$ & 0.657 & \\
\hline Entrepreneurial Intention & & 0.943 \\
\hline I will make every effort to start and run my own firm & 0.821 & \\
\hline I am determined to create a firm in the future & 0.826 & \\
\hline I have very seriously thought of starting a firm & 0.839 & \\
\hline I have the firm intention to start a company some day & 0.823 & \\
\hline My professional goal is to become an entrepreneur & 0.778 & \\
\hline I am ready to do anything to be an entrepreneur & 0.645 & \\
\hline
\end{tabular}

\subsection{Descriptive statistics and correlations for PA, SN, PBC, and EI}

Table 3 presents the means, standard deviations, and correlations for the variables used in this research. The positive relationship among variables exist in this study. The highest mean among the variables was in subjective norm SN (mean 3.91). It was followed by personal attitude PA (mean 3.76), perceived behavioural control (mean 3.05), and entrepreneurial intention (mean 3.03). According to correlation results for demographic variables, the respondents' 'age' had a negative significant correlation with 'marital status' and significant positive relationship with PA. 'Education' level of the respondents had a significant and positive correlation with 
The Impact of Personal Attitude, Subjective Norm, and Perceived Behavioural Control on ...

only SN. On the other hand, 'marital status' was negatively correlated with PA. However, El had a significant and positive relationship with PA, SN and PBC.

Table 3. Mean, standard deviations, and correlations

\begin{tabular}{|c|c|c|c|c|c|c|c|c|c|}
\hline Variables & Mean & SD & 1 & 2 & 3 & 4 & 5 & 6 & 7 \\
\hline Age & 1,70 & 0,78 & 1 & & & & & & \\
\hline Education & 2,88 & 0,89 & .123 & 1 & & & & & \\
\hline Marital Status & 1,68 & 0,47 & $-.391^{* *}$ & -.103 & 1 & & & & \\
\hline $\begin{array}{l}\text { Enterpreneural } \\
\text { Intention }\end{array}$ & 3,03 & 1,12 & .052 & .042 & -.093 & 1 & & & \\
\hline Personal Attitudes & 3,76 & 0,92 & $.145^{*}$ & .086 & $-.173^{*}$ & $.648^{* *}$ & 1 & & \\
\hline Subjective Norm & 3,91 & 0,87 & .055 & $.180^{* *}$ & -.010 & $.314^{* *}$ & $.316 * *$ & 1 & \\
\hline $\begin{array}{l}\text { Perceived } \\
\text { Behavioral Control }\end{array}$ & 3,05 & 0,92 & .126 & .099 & -.060 & $.631^{* *}$ & $.452 * *$ & $.453^{* *}$ & 1 \\
\hline
\end{tabular}

$* \mathrm{P}<0.05 ; * * \mathrm{P}<0.01$

To test hypothesis 1 , Table 4 shows that personal attitude PA significantly and positively influenced El. This means that women who have good overall perceptions of the concept of entrepreneurship are more likely to have entrepreneurial intentions, or more precisely, to start companies one day. Thus, government, media, and other relevant institutions should promote entrepreneurship in order to form better positive perceptions in minds of women in order to increase their entrepreneurial intentions. Therefore, hypothesis 1 is supported.

In testing Hypothesis 2, Table 4 shows that PBC significantly and positively influenced entrepreneurial intentions which means that self-efficacy or a belief of personal ability to succeed and perform a task or control the process of creating a company plays an important role in increasing entrepreneurial intentions. Therefore, hypothesis 2 is also supported.

In regards to Hypothesis 3, Table 3 shows that SN did not significantly affect EI, but it did have a significant and positive effect on PA and PBC. This means that the environment in which an individual acts and lives, as well as family, friends, and colleagues significantly impact the way an individual thinks about his/her own abilities to perform actions of entrepreneurship. Therefore, while hypothesis 3 is not supported, hypotheses 4 and 5 are.

Finally, regarding demographic variables and their impact on PA, SN, and PBC, Table 3 indicates that only education has a significant and positive impact on SN. Age, education, and marital status do not have a significant effect on PA, SN, and PBC. Since education has a significant impact on $S N$, hypothesis 7 is partially supported but, hypotheses 6 and 8 are rejected. 
Table 4: Path analysis of the relationship among demographic variables, personal attitudes, subjective norm, perceived behavioral control, and entrepreneurial intention

\begin{tabular}{lcccc}
\hline $\begin{array}{l}\text { Demograhic } \\
\text { Variables }\end{array}$ & $\begin{array}{c}\text { Subjective } \\
\text { Norm }\end{array}$ & $\begin{array}{c}\text { Personal } \\
\text { Attitudes }\end{array}$ & $\begin{array}{c}\text { Perceived } \\
\text { Behavioral Control }\end{array}$ & $\begin{array}{c}\text { Entrepreneurial } \\
\text { Intention }\end{array}$ \\
\hline Age & 0,003 & 0,134 & 0,101 & $-0,081$ \\
Education & $0,167^{*}$ & 0,087 & 0,064 & $-0,028$ \\
Marital Status & $-0,152$ & $-0,013$ & $-0,264$ & $-0,06$ \\
Subjective Norm & & $0,477^{* * *}$ & $0,332^{* * *}$ & $-0,038$ \\
Personal Attitudes & & & & $0,533^{* * *}$ \\
Perceived & & & & $0,562^{* * *}$ \\
Behavioral Control & & & &
\end{tabular}

*P< 0.05 ; $^{* * P}<0.01$; $^{* * *} \mathrm{P}<0.001$

\section{Conclusion}

This study tried to test the proposed entrepreneurial intention model by examining the effects of PA, SN, and PBC, as affected by demographic variables, on El of women in $\mathrm{FBiH}$. The findings show that $\mathrm{SN}$ has a positive influence on PA and PBC but it does not significantly affect El. On the other hand, PA and PBC have a significant and positive effect on El.

The results of this study imply that there are higher probabilities to increase the entrepreneurial intentions of women who managed to form more positive perceptions about entrepreneurship throughout their lives. However, SN or the family, friends, and environment have a strong impact on the formation of those perceptions in the minds of women. These results also indicate that $\mathrm{SN}$ has a strong influence on women's PA towards entrepreneurship, as well as on the belief that they can create and manage to establish new companies or businesses. In addition, $\mathrm{SN}$ has a positive and significant effect on PBC. The women in FBiH who have high self-confidence and support from their environment have a higher tendency to establish new businesses. They see it as an opportunity for their future. While the study found positive and significant relationships among the variables that are consistent with the literature (Liñán and Chen, 2009), there was no directly positive and significant relationship between SN and El. Previous studies which found indirect relationship between SN and El through both PA and PBC (Liñán and Chen, 2009; Krueger et al., 2000; Autio et al., 2001) support this results. The Bosnian environment can also serve as an explanation for these findings. People in $\mathrm{FBiH}$ do not have an entrepreneurial culture since this small country is still going through a transitional process from socialism to open market economy. Government policies which still maintain socialistic traditions such as high tax rates and license procedures for company establishment are also not encouraging entrepreneurship. Because of these reasons, potential entrepreneurs in this country are discouraged 
The Impact of Personal Attitude, Subjective Norm, and Perceived Behavioural Control on ...

from getting involved in entrepreneurial activities and their perceptions about their own capabilities and skills regarding the establishment and running of companies are generally negative. The GEM report of 2012 supports this.

PBC was the most highly rated type among the four variables in the El model. It also significantly and positively influenced EI. PBC can be considered as another type of self-efficacy. These findings suggest that if women have higher beliefs about their own abilities and skills to control the process of creating and running a company, their entrepreneurial intentions will increase.

As in previous models, demographic variables generally did not have a direct impact on El. Rather they impacted El indirectly through the variables of the model. The same was the case in this study. Age did not play a significant role in the analysis, which might be explained by the limited range of participants of different age that were selected in the sample of this study. In addition, marital status of the participants did not impact PA, SN and PBC significantly. However, only demographic variable which had positive and significant effect on SN was education level. The reason for this result may be that when women get more educated, their self confidence tends to increase and therefore their perceptions about getting support from their families and friends increase.

\section{Limitations and Future Research}

This study is limited in a few ways. The results found in this research come from a limited sample. Surveys with higher sample sizes with more participants of different age groups may give different results. Self-reported issue may be another limitation of this study. Further studies should test the relationships among the variables in other cantons of $\mathrm{FBiH}$ and they should also focus on the indirect relationship between SN and El through both PA and PBC.

\section{References}

Ahl, H. (2006). Why Research on Women Entrepreneurs Needs New Directions. Ahl, H. (2006). Why Research on Women Entrepreneurs Needs New Directions. Entrepreneurship Theory and Practice, 30, 595-621. http://dx.doi.org/10.1111/j.1540-6520.2006.00138.x

Ajzen, I. (1987). Attitudes, Traits, and Actions-Dispositional Prediction of Behavior in Personality and Social-psychology. Advances in Experimental Social Psychology, 20, 1-63. http://dx.doi.org/10.1016/S0065-2601(08)60411-6

Ajzen, I. (1991). The Theory of Planned Behavior. Organizational Behavior and Human Decision Processes, 50(2), 179-211. http://dx.doi.org/10.1016/0749-5978(91)90020-T

Ajzen, I. (2001). Nature and Operation of Attitudes. Annual Review of Psychology, 52, 27-58. http://dx.doi.org/10.1146/annurev.psych.52.1.27

Autio, E., Keeley, R.H., Klofsten, M., parker, G.C., \& Hay, M. (2001). Entrepreneural Intent among Students in Scandinavia and in the USA. Enterprise and Innovation Management Studies, 2(2), 145-160. http://dx.doi.org/10.1080/14632440110094632 
Bandura, A., Adams, N.E., Hardy, A. B., \& Howells, G.N. (1980). Tests of the Generality of SelEfficacy Theory. Cognitive Therapy and Research, 4, 39-66. http://dx.doi.org/10.1007/BF01173354

Bandura, A. (1981). Self-referent Thought: A Development Analysis of Self-Efficacy. In J.H.Flavell \& Ross, L. (Eds) Social Cognitive Development: Frontier and Possible Futures. NY: Cambridge University Press.

Baron, R.A. (1998). Cognitive Mechanisms in Entrepreneurship: Why and When Entrepreneurs Think differently than Other People. Journal of Business Venturing, 13(4), 275-294. http://dx.doi.org/10.1016/S0883-9026(97)00031-1

Bianchi, M. \& Henrekson, M. (2005). Is Neoclassical Economics Still Entrepreneurless? Kyklos, 58(3), 353-377. http://dx.doi.org/10.1111/j.0023-5962.2005.00292.x

Bird, B. (1988). Implementing Entrepreneurial Ideas: The Case for Intention. Academy of Management Review, 13, 442-453.

Boyd, N.G. \& Vozikis, G.S. (1994). The Influence of Self-efficacy on the Development of Entrepreneurial Intentions and Actions. Entrepreneurship Theory and Practice, 18, 63-77.

Chandler, G.N. \& Lyon, D.W. (2001). Issues of Research Design and Construct Measurement in Entrepreneurship Research: The Past Decade. Entrepreneurship Theory and Practice, 25(4), 101-113.

Dinc, M. S. \& Huric, A. (2016). The Impacts of Ethical Climate Types on Nurses' Behaviors in Bosnia and Herzegovina. Nursing Ethics, 1-14. http://dx.doi.org/10.1177/0969733016638143

Erikson, T. (1999). A Study of Entrepreneurial Career Choices among MBAs-The Extended Bird Model. Journal of Enterprising Culture, 7(1), 1-17. http://dx.doi.org/10.1142/S0218495899000029

Fayolle, A., Gailly, B., \& Lassas-Clerc, N. (2006). Assessing the Impact of Entrepreneurship Education Programmes: A New Methodology. Journal of European Industrial Training, 30(9), 701-720. http://dx.doi.org/10.1108/03090590610715022

Fishbein, M. \& Ajzen, I. (1975). Belief, Attitude, Intention and Behavior: An Introduction to Theory and Research. New York: Addison-Wesley.

Friedman, B. A., Aziz, N., Keles, I., \& Sayfullin, S. (2012). Predictors of Students` Desire to be an Entrepreneur: Kyrgyzstan, Georgia, and the United States. Eurasian Journal of Business and Economics, 5 (9), 129-140

Gelderen, M., Brand, M., Praag, M., Bodewes,W., Poutsma, E., \& Vangils, A. (2006). Explaning Entrepreneurial Intentions by Means of the Theory of Planned Behavior: Research Working Papers Series, 2, 1-33.

GEM Report. (2011). Retrieved on May 10, 2016, from Global Entrepreneurship Monitor Bosnia and Herzegovina website: http://www.gemconsortium.org/report/48354

GEM Report. (2012). Retrieved on May 10, 2016, from Global Entrepreneurship Monitor Bosnia and Herzegovina website: http://www.gemconsortium.org/report/48575

GEM Report. (2014). Retrieved on May 10, 2016, from Global Entrepreneurship Monitor 2014 Global Report website: http://www.babson.edu/Academics/centers/blankcenter/global-research/gem/Documents/GEM\%202014\%20Global\%20Report.pdf

Koe, W, \& Abdul Majid, I. (2014). Socio-Cultural Factors and Intention towards Sustainable Entrepreneurship. Eurasian Journal of Business and Economics, 7 (13), 145-156 
The Impact of Personal Attitude, Subjective Norm, and Perceived Behavioural Control on ...

Kolvereid, L. \& Isaksen, E. (2006). New Business Start-up and Subsequent Entry into Selfemployment. Journal of Business Venturing, 21(6), 866-885. http://dx.doi.org/10.1016/j.jbusvent.2005.06.008

Kolvereid, L. (1996). Organizational Employment versus Self-employment: Reasons for Career Intentions. Entrepreneurship Theory and Practice, 20(3), 23-31.

Krueger, N. F., (1993). The Impact of Prior Entrepreneurial Exposure on Perceptions of New Venture Feasibility and Desirability. Entrepreneurship Theory and Practice, 18(1), 5-21.

Krueger, N. F., Reilly, M. D., \& Carsrud, A.L. (2000). Competing Models of Entrepreneurial Intentions. Journal of Business Venturing, 15(5-6), 411-432. http://dx.doi.org/10.1016/S0883-9026(98)00033-0

Lee, S. H. \& Wong, P. K. (2004). An Exploratory Study of Technopreneurial Intentions: A Career Anchor Perspective. Journal of Business Venturing, 19(1), 7-28. http://dx.doi.org/10.1016/S0883-9026(02)00112-X

Li-án, F. (2004). Intention-based Models of Entrepreneurship education. Piccola Impresa/Small Business, (3), 11-35.

Li-án, F., \& Chen, Y. W. (2009). Development and Cross-Cultural Application of a Specific Instrument to Measure Entrepreneurial Intentions. Entrepreneurship Theory and Practice, 33(3), 593-617. http://dx.doi.org/10.1111/j.1540-6520.2009.00318.x

Nunnally, J.C. (1978). Psychometric Theory. New York: McGraw-Hill.

Oke, Dorcas.F. (2013). The Effect of Social Network on Women Entrepreneurs in Nigeria: A Case Study of Ado- Ekiti Small Scale Enterprise. International Journal of Education and Research, 1(11), 1-14.

Pearson, R. (2007). Reassessing Paid Work and Women's Empowerment: Lessons from the Global Economy. Feminisms in Development, 201-213.

Reynolds, P.D., Bygrave, W., Autio, E., \& Hay, M. (2002). Global Entrepreneurship monitor. 2002 summary report. Kansas City: Ewin Marion Kauffman Foundation.

Rotter, J. (1966). Generalized Expectancies for Internal versus External Control of Reinforcement. Psychological Monographs, 80(1), 1-28. Retrieved from http://psychyogi.org/rotter-1966-locus-of-control/\#sthash.XSaM0pzW.dpuf. http://dx.doi.org/10.1037/h0092976

Shaver, K.G. \& Scott, L.R. (1991). Person, process, choice: The psychology of new venture creation. Entrepreneurship Theory and Practice, 16(2), 23-45.

Sivarajah, K., \& Achchuthan, S.(2013). Entrepreneurial Intention among Undergraduates: Review of Literature. European Journal of Business and Management, 5(5), 172-186

Shook, C., \& Bratianu, C. (2010). Entrepreneurial Intent in a Transitional Economy: an Application of the Theory of Planned Behavior to Romanian Students. International Entrepreneurship and Management Journal, 6, 231- 247. http://dx.doi.org/10.1007/s11365008-0091-2

Tubbs, M.E. \& Ekeberg, S.E. (1991). The role of intentions in work motivation: Implications for goal-setting theory and research. Academy of Management Review, 16(1), 180-199. http://dx.doi.org/10.5465/AMR.1991.4279004.

Vossenberg, S. (2013). Women Entrepreneurship Promotion in Developing Countries: What Explains the Gender Gap in Entrepreneurship and How to Close it. Maastricht School of Management. 